\title{
Analysis of PM10 high concentration episodes in Warsaw, Krakow and Wroclaw in the years 2005-2017 with application of selected elements of information systems
}

\author{
Dominik Kobus ${ }^{1, *}$, Alicja $\mathrm{Nych}^{2}$, and Izabela Sówka ${ }^{2}$ \\ ${ }^{1}$ Katowice School of Technology, Faculty of Architecture, Civil Engineering and Applied Arts, 40-555 \\ Katowice, Rolna 43, Poland \\ ${ }^{2}$ Wroclaw University of Science and Technology, Faculty of Environmental Engineering, 50-370 \\ Wroclaw, Wyb. Wyspianskiego 27, Poland
}

\begin{abstract}
The analysis and comparison of the situations of episodes of high PM10 concentrations in the air in three selected Polish agglomerations: Krakow, Warsaw and Wroclaw in the years 2005-2017 with application of selected elements of information systems (IT) is provided. The role of information systems (technologies) in high pollution episodes in the considered cities is described and the results of measurements performed under the State Environmental Monitoring as well as meteorological data and the dust concentration modelling results were used for the analysis. A set of indicators and methodology was developed to compare the occurrence of episodes in the area of selected cities.
\end{abstract}

\section{Introduction}

Particulate matters contamination has been one of the most serious environmental problem affecting directly human health for many years. They come from both anthropogenic and natural sources. In the environment, they may appear in the primary form (emitted directly to the atmosphere) or as a secondary pollution (as the results of chemical reactions and precursors of its precursors, i.e. compounds of sulfur, nitrogen or volatile organic compounds) [1]. Primary dust is formed in combustion processes of fuels (mainly solids) and in production. Among sources of anthropogenic origin, there are professional and industrial power industry, industrial technologies, widely understood other stationary (including, among others, local and home furnaces) and mobile sources. The Polish power industry focuses mainly on hard coal, lignite, oil and natural gas, with a significant predominance of solid fuels [2].

Due to the harmful effects on the human body (respiratory and circulatory diseases, cancer) and the properties of dust (i.e. the ability to spread over long distances), it is important to analyze the changes in dust concentrations, in particular high concentration episodes (the

\footnotetext{
*Corresponding author: dominik.kobus@infair.eu
} 
situation of one or multi-day elevated dust concentrations), where the daily limit level is exceeded in more than $50 \%$, i.e. more than $75 \mu \mathrm{g} / \mathrm{m}^{3}$ [3].

Analyzing the results of measurements of dust concentration dependence on air temperature and wind speed, it can be noticed that instantaneous dust concentrations are inversely proportional to both temperature and instantaneous wind speed $[4,5]$. Another factor affecting the occurrence of episodes is so-called temperature inversion. It is characterized by the appearance of air inversion layers in which the temperature rises with altitude. This hinders vertical movements of the air masses and causes accumulation of pollution in the bottom layer, which may lead to a significant increase in their concentration.

Information technology (IT) is widely used during episodes of high air pollution concentrations at various levels and for various purposes [6-8]. Firstly, it is important to collect and process measurement results, especially from automatic stations. So called DAS/CAS systems support the collection and management of data retrieved from measurement stations at the regional level in Poland and also provide data storage for regional public information dissemination systems. At the central level, IT system called JPOAT2.0 is in operation. functions as part of the Environmental Protection Inspection System "EkoInfonet". It is an integrated system based on the relational database server, user application and the Business Intelligence analytical and reporting system. The implemented ETL (Extract, Transform and Load) processes are responsible for, among others, automatic acquisition of data from voivodship systems, its processing, loading into the central database, preparation for a presentation on the CIEP's Air Quality Portal, as well as obligatory reporting to the European Environment Agency system in the frame of XML e-Reporting framework. IT systems are also used to determine the relevant indicators and statistical parameters. They can result directly from legal regulations, such as certain air quality limit or target values and alert thresholds included in the EU and Polish legislation [9], and allow for the air quality assessment and determination of compliance with standards in a given area. They can also be a collection of other parameters used for specific analyzes, developed specifically for their needs, an example of which are the indices proposed in this paper to assess the situation of smog episodes in cities. Furthermore, IT systems are used for mathematical modelling to determine, for example, the spatial extent of an episode and detailed analyze of residents exposure. It can be also a modelling of pollutants chemical transformations and transport or geostatistical techniques integrated with GIS technologies. It is very important to be able to predict the occurrence of an episode and finally its development in the future. For this purpose, both chemical transport models and advanced statistical procedure are used: neural networks, fuzzy logic, optimization algorithms and other artificial intelligence techniques $[10,11]$.

The aim of the work was to indicate the role of information (IT) systems (technologies) during the high pollution situations and determining the possibilities of their use in the assessment and analysis of the comparative situation of high PM10 concentrations in the air (so-called winter smog episodes) on the example three selected Polish agglomerations: Krakow, Warsaw and Wroclaw. An analysis of the episodes occurrences over the last several years has been carried out, as well as a more detailed study of the selected episode from the beginning of 2017.

\section{Characteristics of the area under study}

The study analyzed episodes of high concentrations in the three agglomerations: Warsaw, Wroclaw and Krakow, where the Average Exposure Index for PM2.5 concentration in 2016 was respectively: 22, 23 and $32 \mu \mathrm{g} / \mathrm{m}^{3}$ [12].

Warsaw is the largest city in Poland, located in the central-eastern part of the country, on the Vistula River, at an average height of $100 \mathrm{~m}$ above sea level, on the Central Mazovian 
Lowland. Its area is $517 \mathrm{~km}^{2}$, and the population is over 1 million 700 thousand inhabitants. Warsaw is located in a humid continental climate zone. The influence of a large urban agglomeration on the climate prevailing in the city (the so-called urban heat island) is marked. This results in higher average air temperatures in the city center, more frequent rainfall, and, due to the greater roughness of the terrain, lower wind speed. In the entire Warsaw agglomeration, emission sources related to human activities, such as fuel combustion, communication, municipal economy, as well as technological processes [13], are of decisive importance for the degree of air pollution.

Wroclaw is the second analyzed city. It is located in south-western Poland, on the Odra River, at an average altitude of $125 \mathrm{~m}$ above sea level. The city's area is almost $293 \mathrm{~km}^{2}$, and the population is over 630 thousand people. The city is located in the transitional climate zone, subject to oceanic and continental influences. As in Warsaw, the climatic conditions of Wroclaw also show features characteristic for large urban-industrial agglomerations, including an increase in air temperature. Wroclaw is located on the foreland of the Sudetes, which is connected with the influence of warm fen winds. This phenomenon is felt especially in winter, when the air temperature rises sharply. In the entire agglomeration, western and south-western winds prevail. The low temperatures, which are associated with higher emissions, as well as the formation of low-gradient pressure systems, have a negative effect, which results in windless periods and, consequently, the lack of ventilation in the city. The fog that appears in the autumn and winter season also inhibits the dispersion of pollution. The main sources of dust pollution in Wroclaw are: the so-called 'low emission' or 'low stack emission', coming from the municipal sector, including individual sources of heat generation, as well as small heat plants, and traffic pollution from transport and industrial sector [14].

Krakow, the second in terms of size (over $326 \mathrm{~km}^{2}$ ) and population (over 760 thousand), city in Poland, is located in the southern part of the country, on the Vistula River, the highest of the discussed cities, at an average height of $285 \mathrm{~m}$ above sea level, in a moderate cold climate, with significant rainfall. The location of the city in the valley negatively affects its ventilation. Additionally, it is surrounded by elevations on three sides, which limits the movements of air masses, and almost $3 / 4$ of the year is windless or almost windless (wind reaches not more than $2 \mathrm{~m} / \mathrm{s}$ ). The main sources of dust pollution in Krakow are home furnaces, so-called inflow emission from neighboring towns, local industry and traffic [1516].

\section{Application of IT systems to episodes analysis}

\subsection{Data selection and processing}

For the needs of the study, the results of the PM10 concentration measurements carried out in the area of Cracow, Warsaw and Wroclaw in 2005-2017 were processed and analyzed both by manual method and with the use of automatic analyzers. The data was collected from the resources available on the Chief Inspectorate for Environmental Protection (CIEP) Air Quality Portal [17] which is a part of the aforementioned Polish Air Quality Information System. It should be noted that due to the work cycle and procedures of the Inspection for Environmental Protection services, the results from 2017 are still before the final verification and validation.

The long-term analysis was performed based on data from the urban background station and the so-called industrial stations - focused on the impact of pollution coming from a specific industrial plant or their group. Traffic stations were excluded from these analyzes, due to their relatively low population and spatial representativeness, limited mainly to the 
immediate vicinity of roads with high traffic intensity and heterogeneity and discontinuity of functioning this type of stations in individual cities during the analyzed years.

For each of the cities, a representative daily average concentration value was determined, being the highest concentration of PM10 registered on a given day at the stations. The data series obtained in this way were compared with the episode limit value $\left(75 \mu \mathrm{g} / \mathrm{m}^{3}\right)$, as well as with other high levels - 200 and $300 \mu \mathrm{g} / \mathrm{m}^{3}$ (information and alert thresholds in Polish legislation). This allowed to calculate a number of indicators for the analysis of episodes (e.g. their frequency in particular years), presented in the work in tabular (Tab. 1) and graphic form (Fig. 1).

\subsection{Long-term analysis of episodes}

The Limit Value set for the annual PM10 average concentration $\left(\mathrm{Sa}=40 \mu \mathrm{g} / \mathrm{m}^{3}\right.$ [10]) was exceeded in Krakow in the entire analyzed period, although a decreasing trend of these values can be found. In the other two cities, the problem with meeting this standard is smaller (Fig. 1). In three cities, the permissible number of exceeding the daily level of $50 \mu \mathrm{g} / \mathrm{m}^{3}$ ( $\left.\mathrm{D}>50\right)$ was not met.

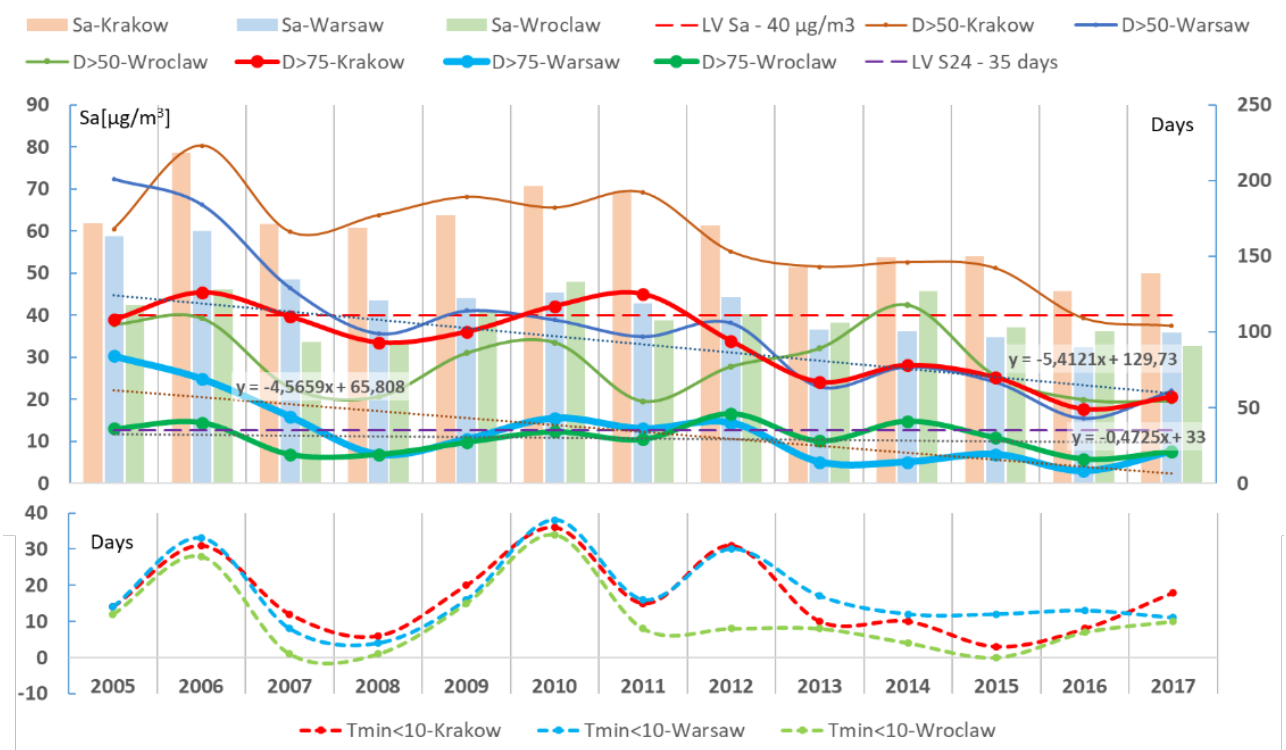

Fig. 1. Variability of selected indicators for high PM10 episodes (source: own preparation based on data published on $[17,18])$.

The number of days with concentrations meeting the definition of an episode (D>75) was the highest in the area of Krakow, then in Wroclaw and Warsaw (here the results are similar). This parameter is closely related to the meteorological conditions prevailing in a given year (especially in the autumn-winter period, e.g. number of days with minimal air temperature below $\left.10^{\circ} \mathrm{C}\left(\mathrm{T}_{\min }<10\right)\right)$ and this trend is declining for the analyzed period for all cities. In particular, 2006 was the year with a high number of episode days, as well as the period from 2010 to 2012.

Maximum daily concentrations of PM10 recorded in three cities can be very high, especially in Krakow (Tab. 1). The most frequent cases of public information level (200 $\left.\mu \mathrm{g} / \mathrm{m}^{3}\right)$ and alarm level $\left(300 \mu \mathrm{g} / \mathrm{m}^{3}\right)$ exceedances took place in Krakow, with the worst situation in year 2006. In Warsaw and Wroclaw such situations occur very sporadically. 
Study of the correlation between the daily concentrations of PM10 in the analyzed period and selected meteorological parameters (Tab. 2) showed the strongest relationship (inversely proportional) with the minimum daily values of air temperature (correlation coefficient values: $-0.59,-0.50,-0.44$ for Krakow, Wroclaw and Warsaw, respectively) as well as the maximum daily wind speed (correlation coefficient values: $-0.38,-0.31,-0.29$ for Krakow, Wroclaw and Warsaw, respectively). This relationship is similar for the included cities, and it occurs most strongly in the case of Krakow.

Table 1. Values of selected indicators for high PM10 episodes (source: own preparation based on data published on [17]).

\begin{tabular}{|c|c|c|c|c|c|c|c|c|c|c|c|c|c|c|}
\hline City & Ind. & 2005 & 2006 & 2007 & 2008 & 2009 & 2010 & 2011 & 2012 & 2013 & 2014 & 2015 & 2016 & 2017 \\
\hline Krakow & \multirow{3}{*}{$\begin{array}{c}\mathrm{D}> \\
75\end{array}$} & 108 & 126 & 110 & 93 & 100 & 117 & 125 & 94 & 67 & 78 & 70 & 49 & 57 \\
\hline Warsaw & & 84 & 69 & 44 & 19 & 29 & 43 & 36 & 40 & 14 & 14 & 19 & 8 & 21 \\
\hline Wroclaw & & 36 & 40 & 19 & 19 & 27 & 34 & 29 & 46 & 28 & 41 & 30 & 16 & 21 \\
\hline Krakow & \multirow{3}{*}{$\begin{array}{l}\mathrm{D}> \\
200\end{array}$} & 6 & 18 & 5 & 4 & 5 & 12 & 8 & 11 & 1 & 1 & 4 & 1 & 9 \\
\hline Warsaw & & 0 & 5 & 0 & 2 & 1 & 1 & 0 & 1 & 0 & 0 & 0 & 0 & 0 \\
\hline Wroclaw & & 0 & 4 & 0 & 0 & 0 & 2 & 0 & 4 & 0 & 1 & 0 & 0 & 1 \\
\hline Krakow & \multirow{3}{*}{$\begin{array}{l}\mathrm{D}> \\
300\end{array}$} & 2 & 9 & 0 & 1 & 0 & 4 & 1 & 3 & 0 & 0 & 0 & 0 & 2 \\
\hline Warsaw & & 0 & 3 & 0 & 1 & 0 & 0 & 0 & 0 & 0 & 0 & 0 & 0 & 0 \\
\hline Wroclaw & & 0 & 1 & 0 & 0 & 0 & 0 & 0 & 0 & 0 & 0 & 0 & 0 & 0 \\
\hline Krakow & \multirow{3}{*}{$\begin{array}{l}\mathrm{S} 24 \\
\max \end{array}$} & 349 & 590 & 266 & 367 & 253 & 396 & 320 & 349 & 226 & 228 & 234 & 299 & 351 \\
\hline Warsaw & & 162 & 372 & 147 & 361 & 237 & 250 & 174 & 223 & 130 & 115 & 131 & 112 & 156 \\
\hline Wroclaw & & 145 & 346 & 122 & 111 & 147 & 239 & 196 & 229 & 152 & 243 & 199 & 145 & 249 \\
\hline
\end{tabular}

Table 2. Correlation coefficients for daily mean concentrations of PM10 (2005-2017) and selected meteo parameters (source: own preparation based on data published on $[17,18]$ ).

\begin{tabular}{|c|c|c|c|c|c|c|c|c|c|c|c|c|}
\hline \multirow[b]{2}{*}{ City } & \multicolumn{3}{|c|}{ Temperature } & \multicolumn{3}{|c|}{ Humidity } & \multicolumn{3}{|c|}{ Pressure } & \multicolumn{3}{|c|}{ Wind } \\
\hline & $\max$ & avg & $\min$ & $\max$ & avg & $\min$ & $\max$ & avg & $\min$ & $\max$ & avg & $\min$ \\
\hline Krakow & -0.39 & -0.49 & -0.59 & 0.07 & 0.21 & 0.17 & 0.23 & 0.22 & 0.20 & -0.38 & -0.33 & -0.34 \\
\hline Warsaw & -0.32 & -0.38 & -0.44 & 0.02 & 0.12 & 0.16 & 0.25 & 0.24 & 0.23 & -0.29 & -0.24 & -0.27 \\
\hline Wroclaw & -0.35 & -0.43 & -0.50 & 0.05 & 0.13 & 0.13 & 0.21 & 0.21 & 0.20 & -0.31 & -0.29 & -0.27 \\
\hline
\end{tabular}

\subsection{Analysis of the selected episode case}

Cases of high PM10 concentrations in the air at the beginning of 2017 (e.g. between 7 and 11 of January, and 17-28 of January, 1-5 and 14-17 of February) were among the more intense episodes in Poland in recent years. Fig. 2 presents average daily values for the selected days of the episode in 2017: January 9 and 11. Observed episodes covered the area of almost the entire country, with particular intensity in the south (especially in the Silesian voivodship) and in the center (Lodz and Masovian voivodships). 

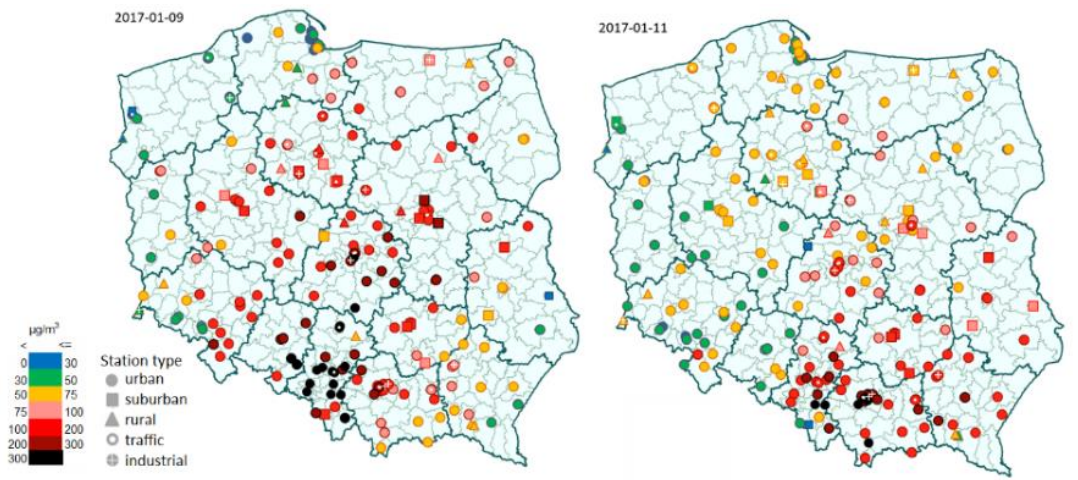

Fig. 2. Daily mean concentrations of PM10 measured in Poland during the selected days of the episode (source: own preparation based on data published on [17]).

Residents of the analyzed cities were also exposed to the risks associated with those episodes. The first one, which took place on January 7-11, 2017, was analyzed in detail on the example of Warsaw. Available data from two urban background measurement stations, two traffic and the same number of suburban stations (Otwock and Konstancin Jeziorna) have been processed to obtain the highest concentration in the city in a specific type of location (Fig. 3).

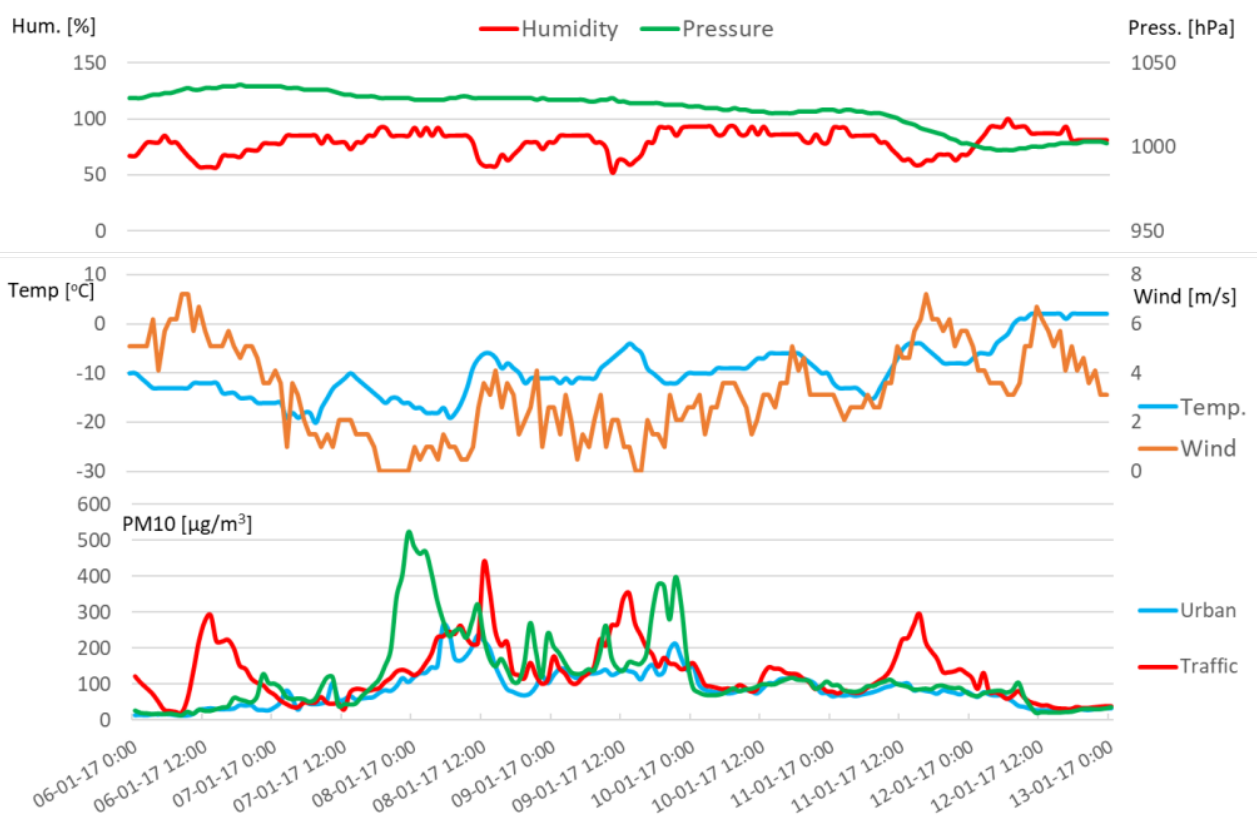

Fig. 3. Hourly PM10 concentration values and selected meteorological parameters during the analysed episode in Warsaw in January 2017 (source: own preparation based on data published on $[17,18]$ ).

The combination of these data with meteorological parameters (from Warsaw-Okecie station) and information about the vertical air temperature profile (Fig. 4) allows for the determination of a clear impact of meteorological conditions on the process of the episode formation. Before and after the episode high PM10 concentrations were recorded mainly in the immediate vicinity of the main roads in Warsaw. The drop in air temperature (to $-20^{\circ} \mathrm{C}$ ) 
affected, among others, the increase in the activity of emission sources associated with household heating systems based on coal combustion, located mainly in neighboring (suburban) locality. The reduction of the horizontal dispersion of pollutants was caused by a significant decrease in wind speed - below $2 \mathrm{~m} / \mathrm{s}$ up to the occurrence of wind silence.

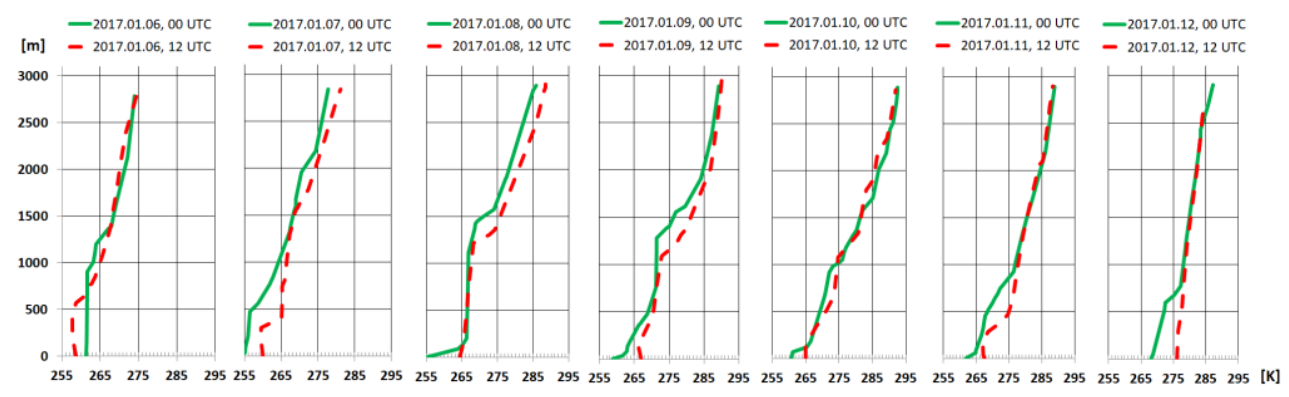

Fig. 4. Vertical profile of the potential air temperature from radiosonde surveys in Legionowo in 612.01.2017 (source: own preparation based on data published on [19]).

Analysis of the variation of potential temperature profile indicates the occurrence of a steady state of atmosphere in the investigated days (7-11 January) with an elevated inversion at about $1500 \mathrm{~m}$ and strong ground inversions, in particular during night periods from 8 to 10 January, when PM10 concentrations were the highest. Maxima were reached in regions of smaller cities, while in the areas of housing estates in Warsaw the concentrations were also very high, similar to those recorded at the traffic stations. This indicates the prevailing contribution of the so-called "low stack emission" in the creation of an episode in the city area. This influence is related both to the inflow of masses of contaminated air from the neighboring area, as well as the use of individual coal stoves and fireplaces also in selected housing estates in Warsaw.

\section{Conclusions}

The use of information systems seems not only optimal but required solution in the process of air quality management, especially in situations of high concentrations of air pollutants. Generally, during the year, the quality of air is strongly affected by road transport in the cities like Warsaw, mainly in central districts. However, in situations of episodes such as those considered in this analysis, emissions from the municipal and housing sector (mainly heating of buildings) are of decisive importance, including also the inflow of pollution from neighboring areas. In the conditions of poor air quality, therefore, an important element, in addition to undertaking measures to reduce emissions, is using of appropriate information systems that allow to provide reliable information and warning of the public.

The implementation of the data presentation system has significantly contributed to the increase of public awareness in the field of air pollution and related threats, and consequently to bottom-up pressure on authorities at various levels of management and undertaking actions aimed at improving the situation. The development of interactive advanced early-warning systems based on numerical methods integrated with e.g. information about current situation and health threats should be conducted by Polish research and IT industry units and go towards, for example, ensuring the interaction of recipients and the ability to conduct multistage analyzes that allow easier tracing of threats, their time variability, as well as understanding of cause and effect relationships between emission sources and corrective actions taken, and concentration levels and health threats. 
The investigations were co-financed within the framework of the order No. 0402/0136/17 with the specific subsidy granted for the Faculty of Environmental Engineering Wroclaw University of Science and Technology (W-7) by the Minister of Science and Higher Education to conduct research and development work and related tasks contributing to the development of young scientists and doctoral students in 2017/2018.

\section{References}

1. K. Juda - Rezler, B. Toczko (ed.), Pyty drobne w atmosferze. Kompendium wiedzy o zanieczyszczeniu powietrza pytem zawieszonym w Polsce (Inspekcja Ochrony Środowiska: IOŚ, Biblioteka Monitoringu Środowiska, Warszawa 2016)

2. GUS, Environment (Departament Badań Regionalnych i Środowiska, Warszawa 2016)

3. J. Iwanek, J. Strużewska, J. Kamiński, P. Durka, D. Kobus, J. Kostrzewa, T. Pecka, Analiza wybranych epizodów wysokich stężén pyłu PM10 z lat 2013-2016, Etap II, Epizody z lat 2015-2016 The work done for CIEP (Instytut Ochrony Środowiska Państwowy Instytut Badawczy: IOŚ PIB, 2017)

4. A. Lochno, Program Ochrony Powietrza dla Województwa Małopolskiego (Urząd Marszałkowski Województwa Małopolskiego, 2017)

5. J. Iwanek, J. Strużewska, J. Kamiński, P. Durka, D. Kobus, J. Kostrzewa, T. Pecka, Analiza wybranych epizodów wysokich stężeń pytu PM10 z lat 2013-2016, Etap II, Epizody z lat 2015-2016 The work done for CIEP (IOŚ PIB, 2017)

6. S. Wiemann, J. Brauner, P. Karrasch, D. Henzen, L. Bernard, Environ Modell Softw 79 (2016)

7. D. Kobus, Przem Chem, 90(2), (2011)

8. D. Kobus, J. Kostrzewa, Information Systems in Management, Vol. 4 (4) (2015)

9. Rozporządzenie Ministra Środowiska z dnia 24 sierpnia 2012 r. w sprawie poziomów niektórych substancji w powietrzu (Dz. U. z 2012 r. poz. 1031)

10. R. Li, Y. Jin, Information Sciences, 435 (2018)

11. J.Wang, X. Zhang, Z. Guo, H. Lu, Expert Syst Appl, 84 (2017)

12. J. Iwanek, D. Kobus, Wskaźniki średniego narażenia dla pyłu PM2,5 w Polsce w 2016 roku The work done for CIEP (IOŚ PIB, 2017)

13. M. Sałata, E. Trębińska, Aktualny stan jakości powietrza w Warszawie (Wojewódzki Inspektorat Ochrony Środowiska w Warszawie, 2002)

14. Ś. Żyniewicz, A. Mikołajczyk, D. Ostrycharz, Ocena poziomów substancji w powietrzu oraz wyniki klasyfikacji stref województwa dolnośląkiego za 2015 rok (Wojewódzki Inspektorat Ochrony Środowiska we Wrocławiu, 2016)

15. http://www.krakow.pl/biznes/1140,artykul,liczby_o_krakowie.html [acsess on 22.01.2018]

16. A. Lochno, Program Ochrony Powietrza dla Województwa Małopolskiego (Urząd Marszałkowski Województwa Małopolskiego, 2017)

17. http://powietrze.gios.gov.pl

18. https://www.wunderground.com

19. http://weather.uwyo.edu 